\title{
VISUOMENĖS POŽIŪRIS İ ŠEIMOS PEDAGOGO REIKMĘ
}

\author{
Laima Kyburienė ${ }^{1}$, Jolita Kšenavičienė ${ }^{1}$, Nerijus Leikus ${ }^{1}$, Donatas Senikas ${ }^{2}$, Vilma Sakalauskienė ${ }^{1}$, \\ Žibuoklè Senikien $\dot{e}^{1,2}$ \\ Kauno kolegijos Këdainiu Jonušo Radvilos studiju centras ${ }^{1}$, Kėdainiai, Kauno medicinos universitetas ${ }^{2}$, \\ Kaunas, Lietuva
}

Laima Kyburienė. Kauno kolegijos Kėdainių Jonušo Radvilos studijų centro Edukologijos katedros vedèja. Mokslinių tyrimų kryptis — edukologija, pedagoginè psichologija.

\section{SANTRAUKA}

Tyrimo tikslas - ištirti visuomenès nuomonę apie šeimos pedagogo poreikį Lietuvoje, nustatyti visuomenès požiūrị $\dot{k}$ šeimos pedagoga, išsiaiškinti visuomenès požiūrị vertinant šeimos pedagogo specializaciju poreiki.

Moderniuoju laikmečiu integraliosios vaiko ir vaikystès sampratos yra pastiprinamos tam tikra politine ideologija, kuri pereina i konkrečias socialines vaikystès apsaugos ir švietimo sritis, stiprina idealiuosius socialinius ir edukacinius šiu sistemu pagrindus. Pastaruoju metu Lietuvoje yra skiriamas gana didelis demesys vaiku visavertès socializacijos procesams. Visame pasaulyje darbui šeimoje rengiami ankstyvos vaikystès mokytojai ar guvernantės. Straipsnyje analizuojama situacija Lietuvoje, t. y. aptariamas visuomenés požiūris ì šeimos pedagogikos specialistu rengima, aiškinamasi, kokias savybes turi išsiugdyti ir kokias kompetencijas turi igyti būsimas šeimos pedagogas, kokiu specializaciju dabar labiausiai reikia. Šiuo tikslu buvo inicijuotas ir atliktas tyrimas „, Šeimos pedagogikos studiju programos ir specialistu (̌̌eimos pedagogu) poreikis Lietuvoje“. Tokia studiju programa leistu parengti specialista edukologa, gebantí sèkmingai prisitaikyti besikeičiančioje darbo rinkoje Lietuvos ir Europos socialineje bei kultūrineje aplinkoje. Toks specialistas galètu mokyti, lavinti, šviesti ar organizuoti mokyma, lavinima, švietima asmenu ar ju grupiu nuo vaikystès iki gilios senatvès.

Duomenims surinkti taikytas šeimu, auginančiu vaikus, anketinès apklausos metodas. Jis leidžia gauti dideli kieki duomenu. Respondentai (̌̌eimos, auginančios vaikus) atrinkti prieinamu atveju būdu. Būtent tokia atranka lèmè generalinés visumos neaiškumo aplinkybè. Duomenys buvo renkami savivaldybiu socialiniuose skyriuose bei ugdymo institucijose apklausiant ten apsilankančius šeimu atstovus ir minètu instituciju vadovus. Tyrimas atliktas 2004 metu lapkričio-gruodžio ménesiais. Anketoje buvo suformuluoti klausimai, iš kuriu atsakymu būtu galima sužinoti šeimu atstovu nuomone apie tam tikru pedagogikos specialistu poreiki.

Tyrimas parodè, kad mūsu visuomenè jau pasirengusi priimti šeimos pedagoga, kaip pagalbininka formuojant vaiko fizini ir psichinị išsivystymq. Labiausiai reikia specialistu, galinčiu savarankiškai dirbti neigalu vaikq auginančioje šeimoje, globos istaigose, specialiosiose globos institucijose.

Raktažodžiai: šeimos pedagogika, šeimos pedagogo specializacija.

\section{IVADAS}

$\mathrm{P}$ er trumpą laikotarpi pasikeitė žmogaus ir visuomenès santykiai, socialiniai santykiai tarp žmoniu. Mūsu vaikams tenka išmokti gerbti vieniems kitus, siekti savo vietos gyvenime nepriklausomai nuo turtinès padèties, tenka išmokti gyventi bendruomeneje, prisitaikyti joje neprarandant savo orumo. Žmonėms nespejjant prisitaikyti prie nuolat kintančiu sąlygų, kyla daugybė socialinių problemų. Ypač tai aktualu mūsų šalyje, kur visuomenès pokyčiai labai ryškūs ir sudètingi. Pedagogai tampa vaiko ugdymo patarèjais ir pa- galbininkais — šeimos pedagogais. Niekas vaikui negali pakeisti šeimos, nes čia yra tai, ko daugiau niekur negali būti — ryškus teigiamas emocinis bendravimas, nuolatinis individualus bendravimas nuo gimimo, altruistinè motinos meile, socialinès patirties perteikimas bendra vaiko ir suaugusiojo veikla. Visgi tam tikru amžiaus tarpsniu vaikui jau nebepakanka bendravimo vien tik su šeimos nariais — kad būtų visavertè socializacija, vaikui reikia bendrauti ir su kitais žmonėmis (Litvinienè, 2000). 
Socialinis ugdymas ir pagalba, tarp ju ir psichologinè-pedagoginè, šeimoms, auginančioms vaikus, yra viena svarbiausių socialinès apsaugos krypčių, kurią igyvendina i̇vairios valstybinès ir nevyriausybinès institucijos. Tokios veiklos svarba yra neabejotina norint užtikrinti visapusišką vaikų gyvenimą dabar ir ateityje: tinkamą buiti, socialini-psichologini saugumą, auklèjimą ir kt. Konkrečių priemonių igyvendinimas priklauso nuo daugelio aplinkybių, pavyzdžiui, valstybès finansinio pajègumo, pakankamų žmogiškujų resursų, aiškios veiklos strategijos. Situacijos analizè, planuojant ir tobulinant tokios pagalbos teikimą šeimoms, auginančioms vaikus, neapsieina be vienokiu ar kitokių tyrimų.

Šiuo tikslu buvo inicijuotas ir atliktas tyrimas „Šeimos pedagogikos studiju programos ir specialistų (šeimos pedagogų) poreikis Lietuvoje“. Tokia studijų programa leistų parengti specialistą edukologą, gebanti sèkmingai prisitaikyti besikeičiančioje darbo rinkoje Lietuvos ir Europos socialinejje bei kultūrinejje aplinkoje. Toks specialistas galètų mokyti, lavinti, šviesti ar organizuoti mokymą, lavinimą, švietimą asmenų ar jų grupių nuo vaikystès iki gilios senatvès.

Tyrimo objektas - visuomenès požiūris $\mathfrak{i}$ šeimos pedagogo reikmę Lietuvoje.

Tikslas - ištirti visuomenès nuomonę apie šeimos pedagogo poreiki Lietuvoje.

\section{Tyrimo uždaviniai:}

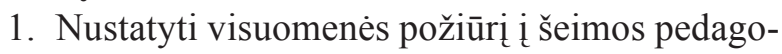
go poreiki.

2. Išsiaiškinti visuomenès požiūrị vertinant šeimos pedagogo specializacijų poreiki.

Vaikai visuomenejje yra svarbi specifinè socialinè grupè. Jie - nesubrendę žmonès, todèl yra priklausomi nuo suaugusiujų, nors ir turintys ypatingą statusą visuomeneje. Vaikai suteikia suaugusiesiems naujus vaidmenis, žyminčius interpersonalinès ir intergrupinès sąveikos su vaikais, socialines ir kultūrines prasmes bei reikšmes (motina, tèvas, auklè, mokytojas, globejjas ir kt.).

Moderniajam laikmečiui būdinga tai, kad integraliosios vaiko, vaikystès sampratos yra pastiprinamos ir tam tikra politine ideologija, kuri pereina į konkrečias socialines vaikystès apsaugos bei švietimo sritis, stiprina idealiuosius socialinius bei edukacinius šių sistemų pagrindus (Juodaitytè, 1999).

Lietuvos visuomenejje vaikai jau pradedami suvokti kaip tam tikra socialinė grupé, turinti daugiareikšmi socialinị ir kultūrini statusą. Savo socialinio vaidmens vertingumu bei socialinès sąveikos reikšmingumu vaikų grupė daro netiesiogini poveiki ir suaugusiujų socializacijai. Socialiai ir pedagogiškai apleisti vaikai ateityje gali tapti ne tik socialine našta visuomenei, bet ir socialinių ar net ekonominių bei politinių krizių priežastimi. Jau šiandien tokie vaikai valstybei ir visuomenei kainuoja daugiau, nei visos veiksmingos prevencinès programos kartu paèmus. Baisiausia, kad vaikai, nerasdami pagalbos, negalèdami patys išspręsti iškilusiu problemu ir nematydami išeities, ryžtasi savižudybei. Tokių atvejų vis daugeja (Paliokienè, 1999).

Pastaruoju metu Lietuvoje yra skiriamas gana didelis dèmesys vaikų visavertès socializacijos procesams. Itin gaji socialiai sveikos kartos brandos ideja. Ši filosofija yra siejama ne tik su dabartimi, bet ir su ateitimi (Šliogeris, 1996).

Visame pasaulyje rengiami ankstyvos vaikystès mokytojai ar guvernantès darbui šeimoje (Griffith, Aharon, 1997). Mokslas trunka 2-3 metus, atitinkamai gaunamas išsilavinimas, leidžiantis dirbti su vaikais šeimoje. Mūsų šalyje iki šiol tokiam darbui buvo rengiamos auklès. Parengtas auklès rengimo standartas apibrèžia minimalius reikalavimus: profesines kompetencijas, mokymo tikslus, turini ir baigiamaji ivertinimą. Standartas parengtas orientuojantis i III profesinio išsilavinimo lygi (Matulevičienè, Zavadskis, 2001).

Dabartinèje visuomenèje auklè šeimoje - ne igeidis, o būtinybè. Praèjo tie laikai, kai moterys veržèsi namo vaikų auginti: tai didelè prabanga, kurią sau leisti gali ne kiekviena Lietuvos moteris. Mama suteikia vaikui meilę, šilumą, saugumo jausmą, bet šiame modernių technologijų amžiuje vaikui reikia kur kas daugiau, norint issitvirtinti pasaulyje - tai ir informacinès-komunikacinès kultūros igūdžiai, gimtosios ir užsienio kalbų žinojimas, gebèjimas bendrauti, kūrybiškai reaguoti $\mathfrak{i}$ šiuolaikinio pasaulio pokyčius (Neuman, 2003).

Auklèmis šiandien Lietuvoje dirba skirtingo amžiaus ir ivvairiausių profesijų moterys: ir ką tik baigusios vidurinę mokyklą merginos, dèl ịvairių aplinkybiu nespejusios igyti jokios profesijos, ir pagyvenusios moterys. Galètume teigti, kad ši profesija Lietuvoje kol kas yra „nelegali““. Ar saugu samdyti auklę? Kam mes patikime savo didžiausią turtą — vaikus? 
Per pirmuosius trejus vaiko gyvenimo metus jo smegenys užauga $70-80 \%$. Todèl tai, ką investuos tèvai ir kiti artimi žmonès į mažą vaiką, yra nepaprastai svarbu. Būtent vaikystejje dedamas pamatas tiek fiziniam, tiek protiniam išsivystymui. Visame pasaulyje kreipiamas itin didelis dèmesys i vaiko auklejjimą ankstyvojoje vaikystejje (Bowman, 2003), rengiamos rèmimo programos (Gallagher \& Clifford, 2000).

Patikèti savo vaiką atsitiktiniam, neturinčiam pedagoginio išsilavinimo, medicininių žinių žmogui - tikrai nesaugu (American Public Health Association \& American Academy of Pediatrics, 2002).

\section{TYRIMO METODAI}

Duomenims surinkti taikytas šeimų, auginančių vaikus, anketinès apklausos metodas. Šis metodas leidžia surinkti didelį kiekį duomenų. Respondentai (šeimos, auginančios vaikus) atrinktos prieinamu atveju būdu. Būtent tokią atranką lèmé generalinès visumos neaiškumo aplinkybè. Generalinè visuma - tai grupé, apie kurią mes norime surinkti informaciją. Dauguma tyrimų siekia, atsitiktinai atrinkus tam tikra generalinès visumos narių skaičiu (atrankinę visumą arba imti), gauti informaciją apie generalinę visumą. Išankstinè sąlyga: turi būti i̇manoma pakankamai aiškiai ir resursų požiūriu racionaliai nusakyti generalinę visumą naudojant, pavyzdžiui, savivaldybių sąrašus, telefonų knygas ir kitus šaltinius. Deja, nagrinėjamu atveju tai komplikuota galimybè.
Pirma, socialinès apsaugos ir ugdymo institucijų teikiamu paslaugu tinklas toks platus, kad formaliai jo gavejjais yra tūkstančiai žmonių, t. y. kiekviena šeima, auginanti bent vieną vaiką. Antra, sudètinga ne tik išnagrinèti prieinamą atrankos šaltini, bet dar sunkiau juo remiantis surasti atsitiktinès atrankos būdu pasirinktus respondentus. Vieni ju gali būti išvykę, kiti yra „nesukalbami“ ir pan. Atsitiktinè atrankos forma (kiekvienas generalinès visumos narys turi turèti galimybę pakliūti i imtị) nagrinèjamu atveju yra labai imli resursams (kelionès, ryšio, laiko ir kitos sąnaudos). Taigi, nors atsitiktinès atrankos forma pagristai laikoma patikimesne, nagrinejjamos problemos atžvilgiu buvo pasirinkta neatsitiktinè atranka. Duomenys buvo renkami savivaldybių socialiniuose skyriuose bei ugdymo institucijose apklausiant ten apsilankančius šeimų atstovus ir minètu instituciju vadovus - prieinamus atvejus. Tikslus šeimų atstovų sąrašas pagal savivaldybes pateikiamas lentelèje.

Norint išsiaiškinti šeimos pedagogu poreiki bei galimas funkcijas, buvo apklausta 821 šeimų atstovas. Iš ju $83,5 \%$ sudarè moterys ir $13,5 \%-$ vyrai. Didžioji dalis šeimų atstovų jauni - nuo 20 iki 40 metu — žmonès. Minèto amžiaus tarpsnio net $83,5 \%$ apklaustujuc. Daugiau kaip puse apklaustujų turi aukštesniji $(23,4 \%)$, aukštaji $(26,5 \%)$ ir aukštaji neuniversitetini $(3,1 \%)$ išsilavinimą. Daugiausia tai šeimos, auginančios vieną $(37,6 \%)$ ar du $(40,9 \%)$ vaikus.

Tyrimas atliktas 2004 metu lapkričio-gruodžio mènesiais.

\begin{tabular}{|l|c|}
\hline \multicolumn{1}{|c|}{ Savivaldybė } & Apklaustų šeimų atstovų skaičius \\
\hline Biržų & 10 \\
\hline Jonavos & 50 \\
\hline Kauno & 80 \\
\hline Kėdainių miesto & 340 \\
\hline Kèdainių rajono & 120 \\
\hline Kelmės & 40 \\
\hline Lazdijų & 10 \\
\hline Panevěžio & 30 \\
\hline Pasvalio & 20 \\
\hline Radviliškio & 10 \\
\hline Raseinių & 30 \\
\hline Šiaulių & 21 \\
\hline Šilalės & 20 \\
\hline Ukmergės & 40 \\
\hline Iš viso & $\mathbf{8 2 1}$ \\
\hline
\end{tabular}




\section{REZULTATAI}

Anketoje buvo suformuluoti klausimai, atsakymai i kuriuos leistų išsiaiškinti šeimų atstovu nuomonę apie tam tikru pedagogikos specialistu poreikį. 26\% apklaustujų nurodè, kad šeimos pedagogu labai reikia ir 39\%, kad reikia. Matematinè statistika atlikta tikimybiu palyginimo metodu (jei $p>0,05$ - atsakymu tikimybès nesiskiria, jei $\mathrm{p}<0,05$ - skiriasi). Taigi galima daryti prielaida, kad šeimos pedagogai, respondentų nuomone, yra reikalingi specialistai Lietuvoje (1 pav.).

Respondentų buvo prašoma pareikšti nuomonę apie šeimos pedagogikos specialistu specializaciju poreiki. Apklausos rezultatai parodè, kad labiausiai reikia specialistų, galinčiu savarankiškai dirbti šeimoje $-43 \%$ ir šeimoje, auginančioje neigalu vaiką - 58\%, taip pat galinčių dirbti su šeima specialiosiose globos institucijose $-53 \%$, globos istaigose $-43 \%$ ir kt. $(\mathrm{p}>0,05)$. Pagal tikimybiu palyginimo metodą yra reikalingi šių specializacijų pedagogai (2 pav.).

\section{REZULTATŲ APTARIMAS}

Išanalizavus šeimų atstovų apklausos duomenis matyti, kad ši pedagogikos grandis Lietuvoje dar nèra išplètota, ir yra aiškus šeimos pedagogi-

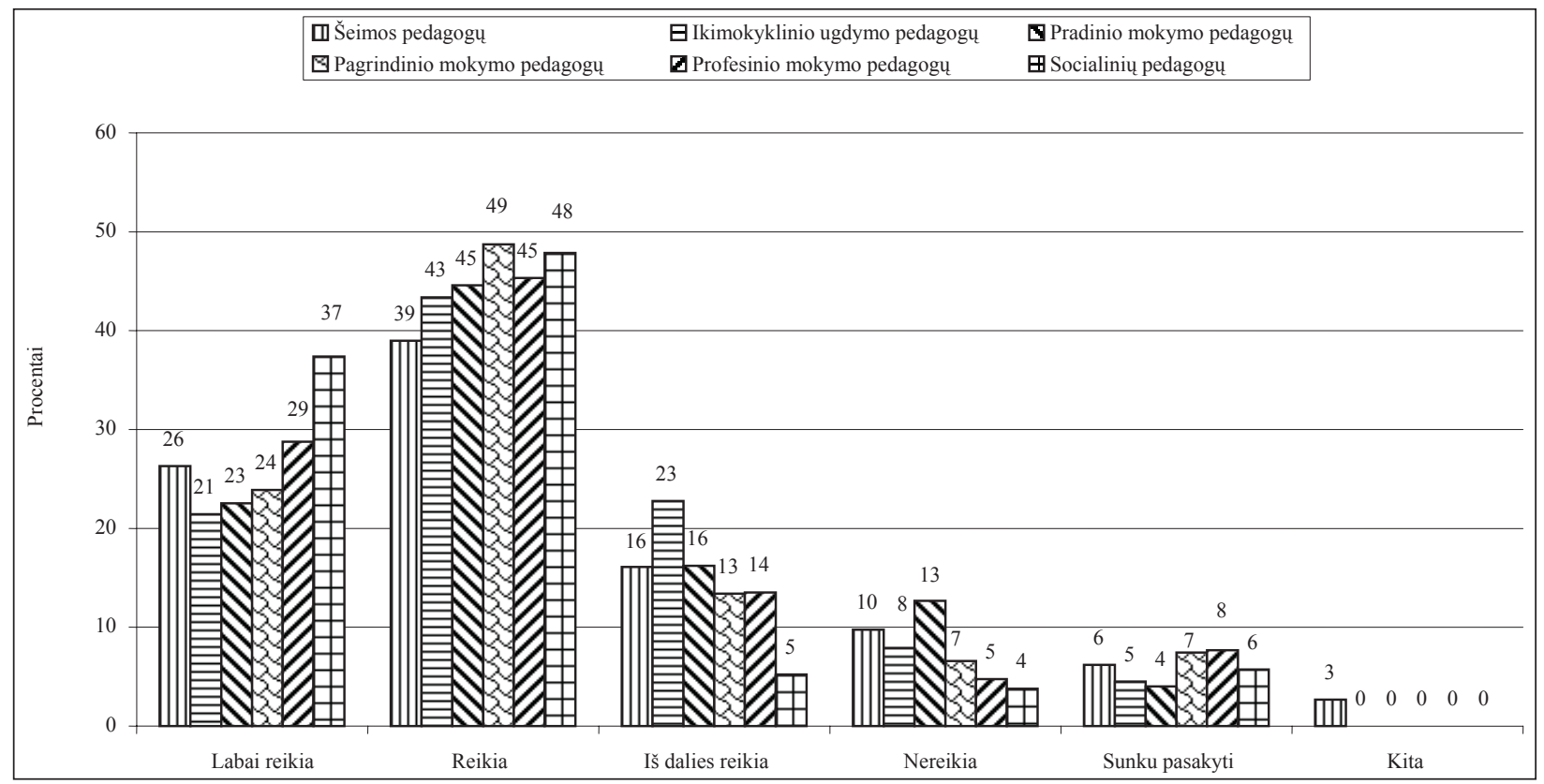

1 pav. Šeimos pedagogikos specialistų poreikis

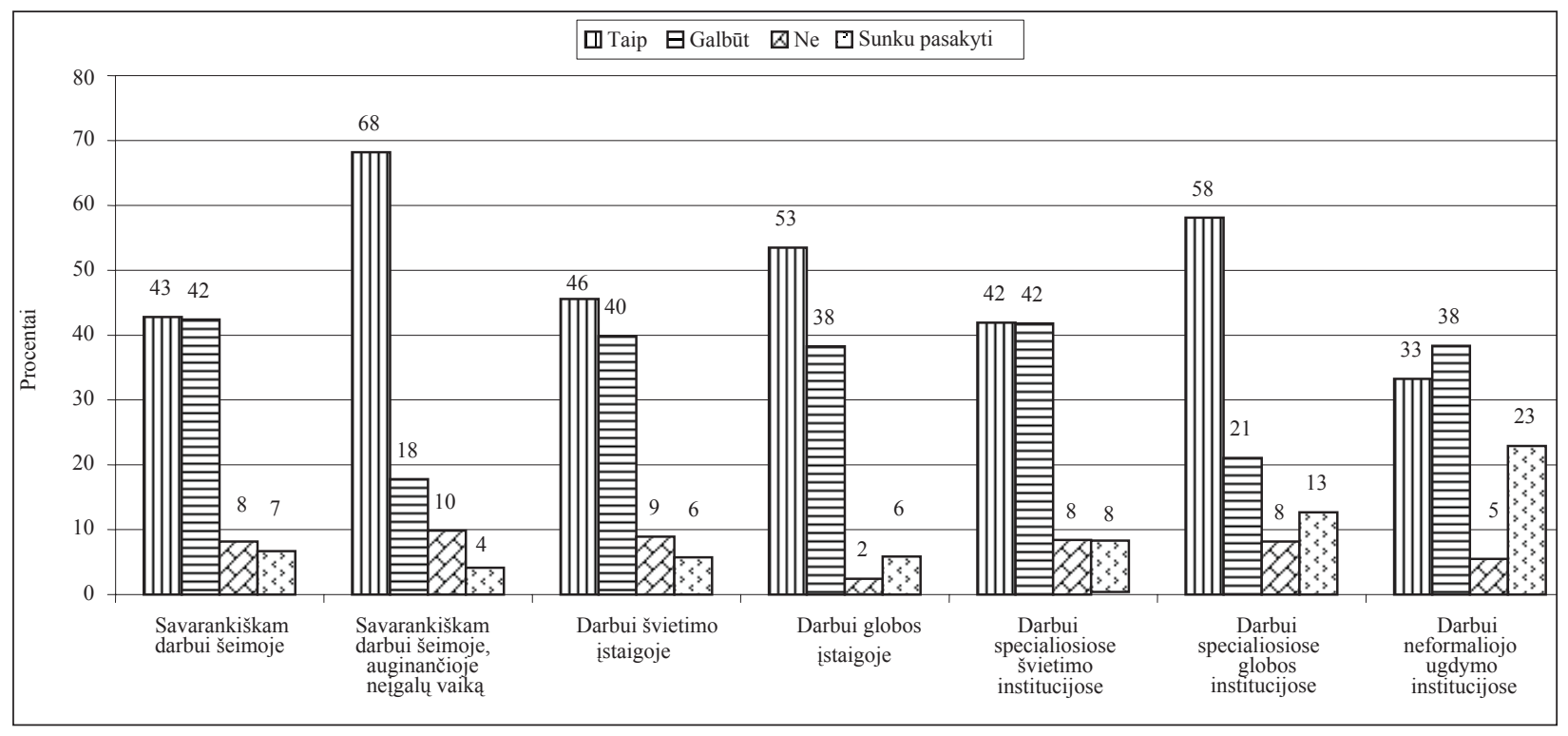

2 pav. Šeimos pedagogikos specialistų specializacijų poreikis 
kos specialistų poreikis. Išryškejjo, kad labiausiai reikia šeimos pedagogikos specialistų, galinčiu savarankiškai dirbti šeimoje, auginančioje neigalų vaiką. Taip pat paaiškejjo, kad būtų tikslingiau rengti šeimos pedagogikos specialistus ne tik darbui šeimoje, bet ir galinčius dirbti globos bei specialiosiose globos istaigose.

Pastaraisiais dešimtmečiais Lietuvoje didèja dèmesys šeimai. Šiuolaikiniai mokslai - edukologija, psichologija, istorija, sociologija, teisè, ekonomika, etika ir kiti - nagrinèja įvairiausius šeimos gyvenimo klausimus. Šių mokslų pagrindu formuojasi naujas integralus mokslas - šeimotyra, kurio objektas - šeima kaip holistinis biosocialinis vienetas, kaip nepakartojamas fenomenas (Rupšienè, 2001). Šeima - svarbiausioji vaiku ugdymo institucija, svarbiausia mikroaplinka, kurioje vykdoma vaiku socializacija. Edukologijos mokslo sistemoje netgi išsiskiria specialus mokslas - šeimos edukologija, kuris, pasak Z. Bajoriūno, šeimos gyvenimą nagrinejja kaip vaiku auklèjimo veiksni (Bajoriūnas, 2004). Taigi edukologija praturtina šeimotyros mokslą duomenimis apie šeimą kaip vaikų socializacijos institucija, apie ugdymo šeimoje principus, dèsningumus ir technologijas, apie tėvų švietimo programas. Edukologinis šeimos tyrimo aspektas itin reikšmingas taikomuoju požiūriu: žmonès gauna informacijos, kuri padeda sèkmingiau ugdyti savo vaikus. Ne- normalūs emociniai vaiko ryšiai šeimoje skatina ivvairius jo socializacijos sutrikimus bei asmenybès raidos destrukcijas (psichofizines, emocines, valios, charakterio) (Aramavičiūtè, 2005).

Atlikto tyrimo rezultatai leidžia teigti, kad mūsų visuomenè jau pasirengusi priimti i šeimą šeimos pedagogą, kaip pagalbininką formuojant vaiko fizini ir psichini išsivystymą.

\section{IŠVADOS}

1. Šiandien šeimos pedagogika — tai mažiausiai išplètota pedagogikos grandis Lietuvoje.

2. Pastebimas gana stiprus šeimos pedagogikos specialistų poreikis. Mūsų visuomenè jau pasirengusi priimti šeimos pedagogą, kaip pagalbininką formuojant vaiko fizini ir psichini išsivystymą.

3. Labiausiai reikia specialistų, galinčiu savarankiškai dirbti šeimoje ir šeimoje, auginančioje neigalų vaiką, taip pat galinčiu dirbti globos įstaigose bei specialiosiose globos institucijose.

4. Tiek užsienio šalių patirtis, tiek atlikto tyrimo rezultatai rodo, kad nèra tikslinga rengti šeimos pedagogus tik darbui šeimose. Anglijoje, Amerikoje, Vokietijoje, Ispanijoje išsilavinimas suteikia teisę dirbti šeimose, ikimokyklinèse ịstaigose, su neigaliais vaikais tiek individualiai šeimose, tiek globos istaigose.

\section{LITERATŪRA}

American Public Health Association\&American Academy of Pediatrics. (2002). Carng for our children:national health and safety performance standarts: Guidelines for out-of-home child care programs (2nd ed.). Washington, DC: American Public Health Association.

Aramavičiūtè, V. (2005). Auklejiimas ir dvasine asmenybès branda. Vilnius.

Bajoriūnas, Z. (2004). Šeimos ugdymo mokslas ir praktika. Vilnius.

Bowman, B., T. (2003). Family engagement and support. D. Cryer \& R. M. Clifford (Eds.), Early childhood education and care in the USA. Baltimore, MD: Paul H. Brookes.

Gallagher, J. \& Clifford, R. (2000). The missing support infrastructure in early childhood. Early Childhood Research \& Practice (Online), 2 (1).

Griffith, S., Aharon, L. (1997). The au Pair and nanny's guide. Oxford. P. 22-25.
Juodaitytè, A. (1999). Vaikystès ideologija: tradiciniu ir moderniuju sampratų sankirtos. Tiltai, 3-4 (8-9), $53-64$.

Litvinienè, J. (2000). Vaikas — šeimos ir darželio sąveikos subjektas ir objektas. Socialiniai-edukaciniai pokyčiai ikimokykliniame ugdyme: mokslo darbu rinkinys (pp. 113-119). Klaipèda.

Matulevičienè, R., Zavadskis, V. (2001). Auklès rengimo standartas. Vilnius.

Neuman, S., B. (2003). From rhetoric to reality: The case for high-quality compensatory prekindergarten programs. Phi Delta Kappan, 85 (4), 286-291.

Paliokiene, G. (1999). Socialiniai pedagogai ugdymo institucijoje. Socialinis ugdymas. D. 2. Vilnius: Lietuvos demokratiškumo kolegija.

Rupšienè, L. (2001). Šeimotyros Ł̇vadas. Klaipèda.

Šliogeris, A. (1996). Sudužusio pasaulio vaikai. Mokykla, $2,1-8$. 


\title{
THE ATTITUDE OF THE SOCIETY TOWARDS THE NEED OF A FAMILY EDUCATOR
}

\author{
Laima Kyburiene் $\dot{1}^{1}$,Jolita Kšenavičiené ${ }^{1}$, Nerijus Leikus ${ }^{1}$, Donatas Senikas ${ }^{2}$, \\ Vilma Sakalauskiené ${ }^{1}$, Žibuoklè Senikiené $\dot{~}^{1,2}$ \\ Kaunas College Kèdainiai Jonušas Radvila Study Centre ${ }^{l}$, Kèdainiai, Kaunas Medical University², \\ Kaunas, Lithuania
}

\begin{abstract}
The modern times are marked by the fact that the integral child and childhood notions are strengthened by certain political ideology, that penetrates into particular social childhood protection and education fields, strengthens the ideal social and educational principles of the systems. Recently quite great attention has been paid to the processes of children's wholesome socialization in Lithuania. In the whole word there are early childhood teachers and governesses trained to work in families. The article analyses the situation in Lithuania, i. e. considers the public opinion about training family educators, clears out the features that must be developed and competences obtained by the future family educator, and what specializations are mostly needed now. According to the aim, mentioned above, the following research was carried out: "Demand for Family Education study program and specialists (family pedagogues) in Lithuania. The program of Family Pedagogue would enable to prepare specialist-pedagogue, that would be able to adapt to the social and cultural space of volatiling labour market in Lithuania and Europe. Family pedagogue would be able to teach, train, educate or organize teaching, training, educating process for persons or groups from childhood to senescence."

Method of the research - the guestionnaire poll, which was filled in by families having children. This method allows to select big data. The method of accessible case was used to select the respondents. Obscurity factor of general totality determined this kind of selection of respondents. The locations for selecting the data were the following: Departments for Social Affairs of municipalities and Educational Institutions. The heads of the departments, educational institutions and representatives of families were asked to fill in the questionnaire. The research was made in November / December, 2004. The questionnaire contained questions representing the opinion of respondents of the demand for certain specialist-pedagogue.

The survey showed, that our society is ready to accept the family pedagogue into a family as a helper in the formation of a child's physical and mental development. The greatest need is for the specialists being able to work independently in the families with a disabled child, to work at educational institutions, special caring institutions.
\end{abstract}

Keywords: family pedagogics, specialization of family pedagogue.

Gauta $2005 \mathrm{~m}$. rugsèjo $12 \mathrm{~d}$.

Received on September 12, 2005

Priimta 2006 m. gegužès $25 \mathrm{~d}$.

Accepted on May 25, 2006
Laima Kyburienė
Kauno kolegijos Kèdainių Jonušo Radvilos studijų centras
(Kaunas College Kèdainiai Jonušas Radvila Study Centre)
J. Basanavičiaus g. 4, LT-57178 Kèdainiai
Lietuva (Lithuania)
Tel+37068746306
E-mail laima13@gmail.com 